\title{
A karanténok története II.
}

\author{
Felkai Péter dr. \\ Debreceni Egyetem, Általános Orvostudományi Kar, Belgyógyászati Intézet, \\ Endokrinológiai Nem Önálló Tanszék, Utazásorvostani Tanszéki Csoport, Debrecen
}

Az utolsó nagy pestisjárványhullám 1666-ban elérte Angliát. A kór két évig tombolt, és 100000 áldozatot szedett. London utcáin állandó volt a pánik és a káosz. A megbetegedettek házának ajtaját eltorlaszolták, és még az egészségeseket sem engedték ki onnan. A járvány a vidéket sem kímélte: Eyam, a Liverpooltól nem messze lévő falu lakosságát a pestis szinte teljesen kiirtotta - ma a szellemfalu idegenforgalmi látványosság. Első áldozata a falu boltosa és segédje volt, aki a Londonból hozatott fertőzött ruhákat árulta. Az emberek ösztönösen bezárkóztak a házukba, és a szülkséges élelmiszerek listáját és az értük járó pénzt a falu végén lévő kőre tették: a vándorárusok ide tették vissza az árut (1. ábra). Így köszön vissza a jelenkori „pizzafutár” őse a történelem lapjairól.

Hasonló óvatossági intézkedéseket vezettek be Olaszföldön. Hogy a borkimérés okozta haszon azért ne károsodjon, az ablakok (buchette del vino) alá kis forgóajtót tettek, hogy személyes érintkezés nélkül lehessen az italhoz jutni (2. ábra).

Angliában a Parlament a karanténintézkedéseket már 1709-ben törvénybe iktatta, de a rendelkezéseket nem nagyon tartották be [1]. Az angol John Howard (17261790), a későbbi neves börtönreformer nagy múve a börtönökről és a karanténok alapelveiről 1789-ben jelent meg [2]. A szerző az Égei-tenger partján fekvő kikötővárosból, Szmirnából (ma: Izmir, Törökország)

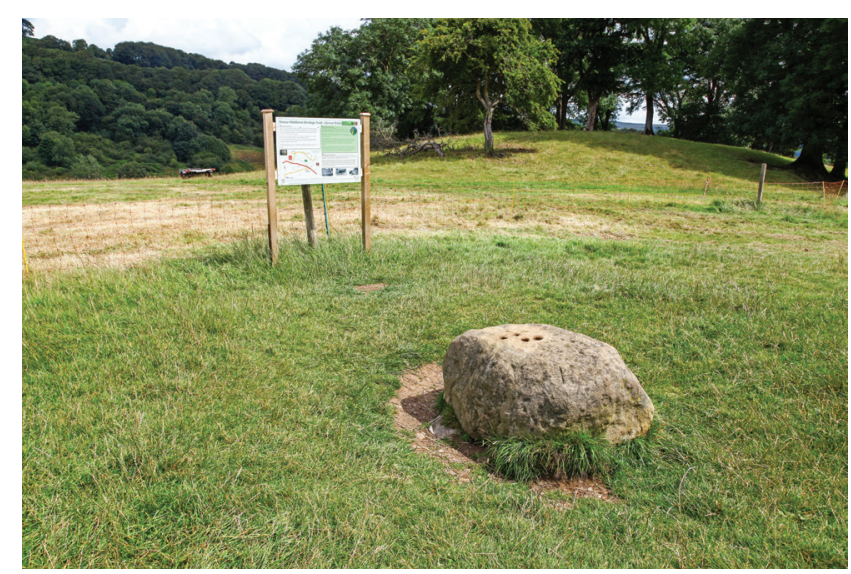

1. ábra

Az Eyam határában álló kó, ahová a hozott árut és az érte járó pénzt tették (az Alamy engedélyével)
Velencébe utazván maga is karanténba került: saját bőrén tapasztalta meg a lazzarettókban uralkodó viszonyokat, melyeket a börtönhöz hasonló nyomorúság jellemzett. A karanténtörvény módosítására (mely a gyarmatok hajózására is vonatkozott) 1799-ben került sor, Sir Gilbert Blane (1749-1834), a tengerészeket sújtó skorbut megelőzését kidolgozó katonaorvos részvételével [3].

Hogy a magyarországi viszonyokra is kitérjünk, nem tudni, hogy Howard munkáját ismerte-e az erdélyi Nyulas Ferenc börtönorvos, később Erdély protomedikusa (ez az országos tisztifőorvosi állásnak felel meg), de meglepően hasonló gondolatokat hangoztatott. Mindenesetre később is élénken érdeklődött a börtönök állapotának megjavítása iránt. Erre utal a többi között, hogy protomedikusi minóségében felemelte szavát az erdélyi börtönökben uralkodó visszamaradottság ellen [4].

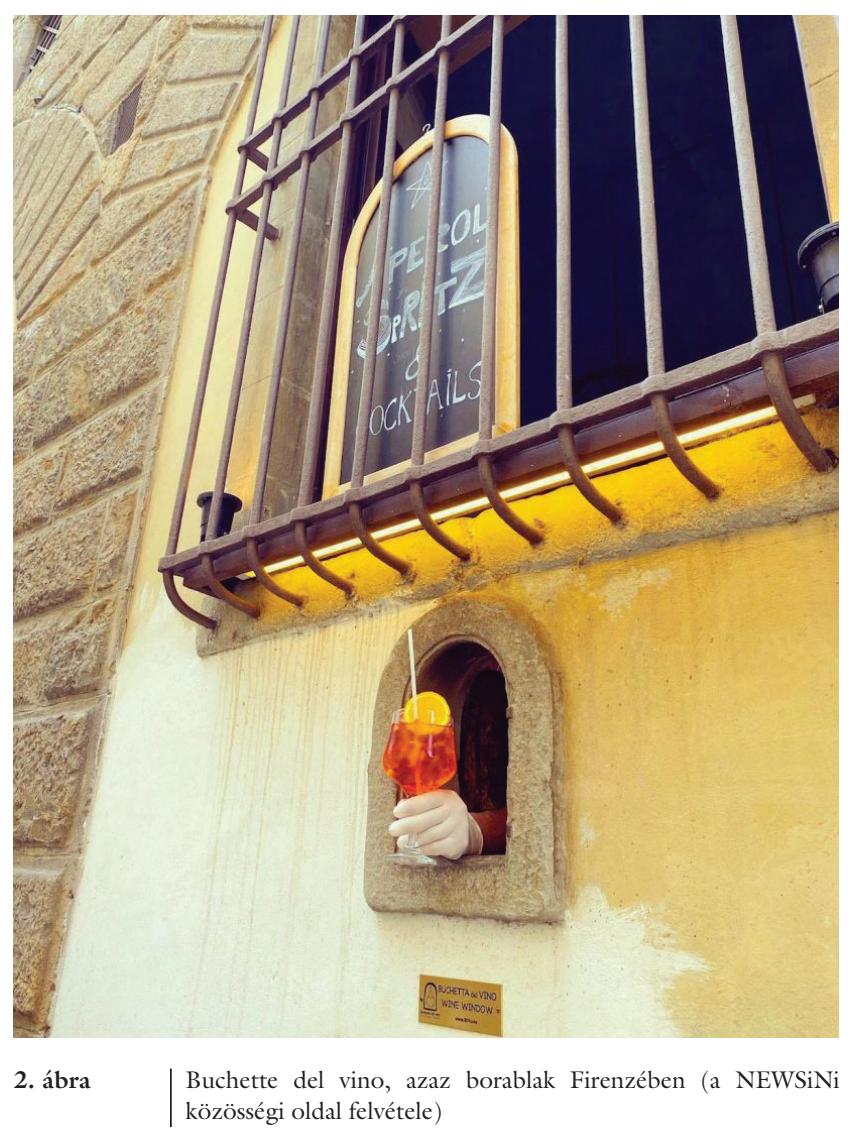


Nyulas 1795-ben, a pestisjárvány idején 53 községben gyógyított, és a himlőoltást is ő ismertette meg Erdélyben.

A magyarországi karanténintézkedésekről írott emlék csak a 18. századtól maradt fenn. A magyar hatósági intézkedések semmivel sem maradtak el a többi országéitól, sőt sok esetben jobbak és szigorúbbak voltak azoknál. Mária Terézia 1770-ben megjelent egészségügyi alaprendelete részletesen szabályozza a vesztegzár idejét, elóírja az őrség szolgálati rendjét, a „veszteglőállomások" helyét stb. [5]. Mivel a környező országokban - félvén a kereskedelem összeomlásától és az éhínségtől sokszor eltitkolták a pestises megbetegedést, a magyar határ menti városok „pestiskémeket” küldtek ki a szomszédos országokba, felmérvén, hogy milyen veszély fenyegeti őket. Ha a járvány elharapózott, egészségügyi bizottságot állítottak fel, és a bizottság pestisorvosokat (pestilentiárius) és pestissebészeket nevezett ki. Ezek feladata volt a lazarénumok ellenőrzése és a kontumáciaházak (a „pestismento”” elkülönített házakat nevezték így) felügyelete. A pestisorvosok azonban sokszor nem diplomás medicinális doktorok voltak, hanem sebészi tevékenységet végző borbélyok. Ám a városi járványkórházakban olyan nyomorúságos viszonyok uralkodtak, hogy az oda beosztott egészségügyi személyzet és a lelki vigaszt nyújtó papok vagy megszöktek, vagy állandóan alkoholmámorban fetrengtek [6]. A pestiskórházakból a túlélők a lazaretumba (magyar kifejezés a lazzarettókra) kerültek, 40 napi megfigyelésre.

A veszteglőház volt tulajdonképpen a karantén, ebben a más vidékről érkező vándorárusokat és vándorló mesterembereket vonták 42 napi vesztegzár alá [7]. Ezek a házak rendszerint a helység szélén, a mezőn voltak, és erős őrség vigyázta a település határában, hogy sem oda, sem onnan ne lehessen közlekedni. A járványőrséget több településen felhatalmazták, hogy a parancsot megszegőket agyonlőjék (!). Sokszor egész településeket vettek körül „veszteglővonalakkal”, és aki azon átlépett (márpedig a határban a mezőgazdasági munkát folytatni és az állatokat eteni kellett), azt néhány helyen a szabályrendelet értelmében felakasztották (!) [8]. Az elkülönítés és a vesztegzár miatt (mivel az állatokat nem tudták legeltetni, a mezőgazdasági munkákat elvégezni) lázadások törtek ki külföldön, de hazánkban is. Az 1831. évi magyarországi kolerajárvány idején ilyen lázadások a Felvidéken a „fokozott röghöz kötés” (kijárási tilalom) miatt és a hatósági intézkedések ellen - így a Duna hajóhídjainak lezárása miatt - Budapesten is kirobbantak [9]. A járvány így adott szelepet a társadalmi feszültségeknek - persze mindegyiket katonai erővel torolták meg.

A 19. századi Európában máshol is a feszítő társadalmi egyenlőtlenségek generálta szegénység miatti kivándorlás az észak-amerikai kontinensre megint szükségessé tette a nagy tömegben érkező, rendszerint nyomorúságos állapotban lévő embertömeg partra lépés előtti elkülönítését. Így 1846-ban a nagy ír éhínség miatt egymillió ember emigrált Kanadába. Egyedül Québecbe 5000

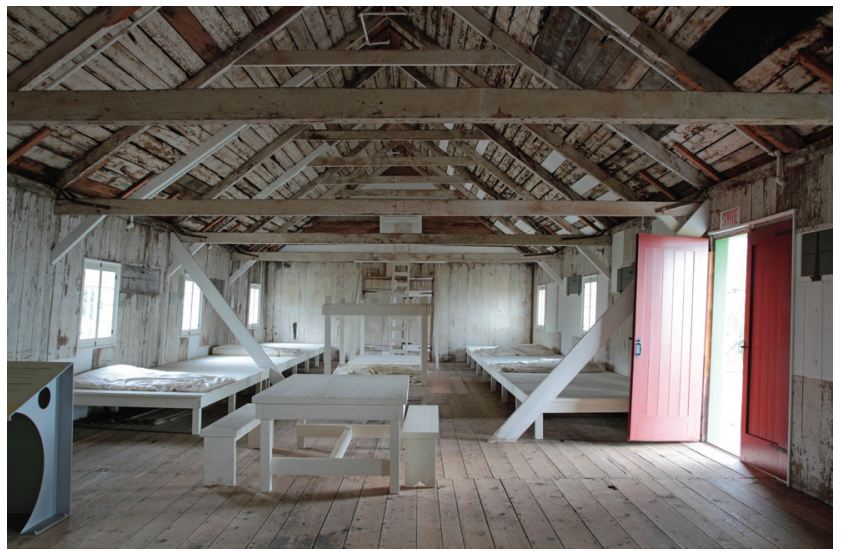

3. ábra

A Grosse Isle-i lazzaretto egyik terme. A szigetet a kanadai kormány 1974-ben nemzeti emlékhellyé nyilvánította (a szerző felvétele)

ember vándorolt be, őket a közeli Grosse Isle szigeten, a tíz évvel azelőtt létesített, a kolerás betegek elkülönítésére szolgáló karanténban helyezték el. Hasonló karanténokat létesítettek a Hudson folyó mentén Montrealban, Torontóban és Saint John városában (3. ábra).

Menekültek nagy számban érkeztek a fiatal Egyesült Államokba is. A menekülteket először a Manhattan-félsziget csúcsán lévő épületben fogadták, de ez az épület nem volt képes ellátni az addig 8 millió érkezőt, ezért a közeli Ellis-szigeten új állomást építettek 1892-ben. Az alkalmat a hajónyi orosz zsidó menekült szolgáltatta, akik nyomorúságos, tetves állapotban érkeztek. Ez a turnus tífuszt terjesztett, míg a következő, az oroszországi pogromok elől menekült emberek kolerát terjesztettek a városban elvegyülve [10]. Az Ellis-szigeti állomás már megfelelt a karanténok követelményeinek is: izolálva volt a szárazföldtől. Az 1890-es évek óta minden bevándorlót orvosi vizsgálatnak vetettek alá, és közülük 700000 nem kapta meg az ún. affidavit-ot, a partra lépést engedélyezó okiratot. Megnyitása óta több mint 25 millió bevándorlót fogadott az intézmény, egészen 1924-ig,

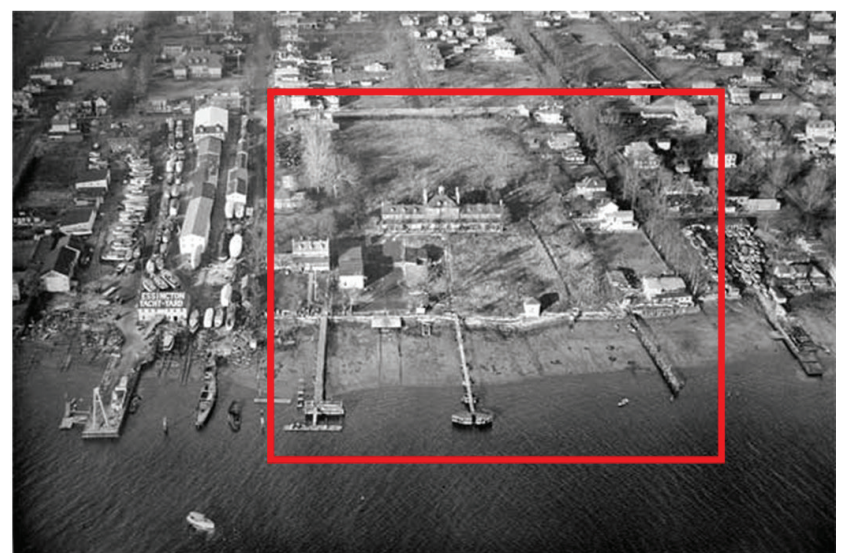

4. ábra $\quad$ A tinicumi 'Philadelphia Lazaretto' légi felvétele 1929-ból. A pirossal jelölt komplexum területén a fő fogadóépület mellett kiegészítő épületek és temető is volt. Az állomás a 20. században hidroplánállomásként múködött (a Philadelphia Free Library, Print and Picture Department tulajdonát képező fénykép) 
amikor először világháborús hadifoglyokat őriztek itt, majd végleg bezárták. Ma történelmi emlékhely, híd köti össze a szárazfölddel, a hidat azonban a helyi hajóstársaság tiltakozása miatt nem használhatják a látogatók.

1793-ban az egyesült államokbeli Philadelphiában a feltehetően Afrikából behurcolt, 5000 áldozatot követelő sárgaláz pusztított [11]. Ezért a közeli, Tinicum nevú kis településen létesítették a 'Philadelphia Lazaretto' karanténállomást (4. ábra). A Philadelphiába tartó hajóknak a Delaware folyó itt lévő kikötőjében kellett megállniuk. Ha fertőzőgyanús volt, vagy átfüstölték, vagy elégették a hajót és az árukat.

Az első fegyencszállítmány 1787-ben érkezett Angliából Ausztráliába. Az angol börtönök túlzsúfoltsága a gyarmatot a fegyencek deportálási helyévé változtatta. Az elítéltek a londoni börtönök embertelen körülményeit a hajókon is megtapasztalhatták: mintegy negyedrészük már útközben meghalt, a fedélzethez láncolva. 1787-től 1868-ig körülbelül 165 ezer elítéltet deportáltak Ausztráliába, akik között sok volt a már Angliában megbetegedett fertőző beteg [12].

A Sydney-öböl nevezetes látnivalója a Manly-félszigeten 1832-ben létesített karanténkomplexum, mely az 1828-ban itt létrehozott gyưjtőtábor utódjául szolgált. Ideális helyen fekszik: pont az öböl bejáratánál, így alkalmas volt az érkezők elkülönítésére. A félszigetet John Hunter kapitány (Arthur Phillip admirálisnak, Sydney alapítójának a helyettese) fedezte fel 1788-ban, és ő adta neki a „Férfiasság” nevet az ott élő bennszülöttek ágyékkötőből kilógó, feltûnő férfiasságát látva. Az Európában 1829-tól 1850-ig pusztító kolerajárvány megelőzésére 1832-ben egy karanténtörvény hozta létre a félsziget legmagasabb részén lévő állomást. A 80 méteres dombra hosszú és meredek lépcsősor vezetett fel. Nemcsak az Angliából érkező elítéltek, de az évek során sok emigráns is érkezett Új-Dél-Wales-be, akiket később már csak orvosi vizsgálat és himlőoltás (!) után engedtek be Sydneybe. Két hatalmas autokláv szolgált az érkezők holmijainak fertőtlenítésére, melyeket azonban csak a 20. században építettek a karantén épületeihez.

A karantén megnagyobbítását és szögesdróttal való elkülönítését az váltotta ki, hogy az egyik bevándorlóhajóval érkezett 200 hajadon egyszer csak eltünt a környező erdőkben... A telep megnagyobbítása időben történt: 1853-ban kikötött az első kétfedélzetes utasszállító hajó, a Beerjapore, fedélzetén 1000 utassal. Közülük 55 még útközben meghalt, 60 pedig a karanténban. Halálukat a bárányhimlő, a skarlát és a tífusz okozta [13]. Az európai emigránsok által behurcolt, 1788-ban kitört himlőjárvány alatt megbetegedetteket - főleg az őslakos abókat - itt ápolták és különítették el. A karantént 1984-ben bezárták, és 1999-ben Történelmi Emlékhellyé nyilvánították. A hely egy darabig parlagon hevert - kivéve a hadsereg által kisajátított részeket -, és csak az egykori internáltak unalmukban kőbe vésett figuráit látogatták a helybeliek. Ám az omladozó épületeket megmenteni

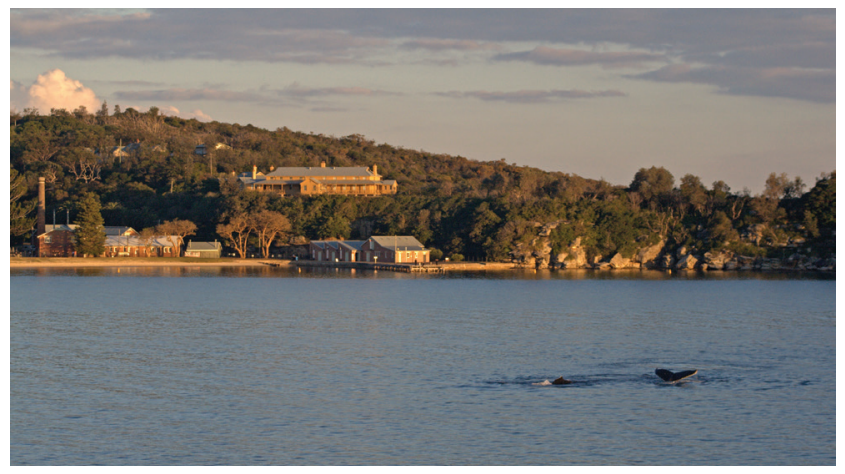

5. ábra

A North Head Quarantine Station a Manly-félszigeten. A jobb alsó sarokban a karantén kikötője, bal oldalon zuhanyozó- és fertőtlenítőhelyiség, a kórház és a füstöléssel fertôtlenítő helyiség. A dombtetőn a lakóépületek (a szerző felvétele)

akarván, a karantén néhány épületét átépítették, és ma méregdrága szállodaként múködnek (5. ábra).

Nemcsak az embereknek, hanem az 1872. évi behurcolt száj- és körömfájás után a kontinensre bevitt állatoknak is karantént írt elő az 1908-ban megszavazott karanténtörvény. Az országba a mai napig nem szabad bevinni sem ételnemút, sem növényt. Az állatokat is karanténba kell helyezni, ezért a 2000-ben Sydney-ben megrendezett olimpián a lovasszámok résztvevői, a takarmánnyal együtt, végig karanténba lettek helyezve. Az állatokat szállító jármúveket is minden alkalommal fertőtlenítették, beleértve a repülőgépeket is.

Mivel a karanténintézkedések súlyosan sértik az állampolgárok szabadságát, viszont közérdekból sokszor szükség van az intézkedések meghozatalára, 1851-tôl kezdődően 14 nemzetközi közegészségügyi konferenciát tartottak ebben a tárgyban. Az első konferenciát az 1929. évi második kolerajárvány után, 1851-ben, Párizsban szervezték meg francia szakemberek [14]. A tanácskozások során meghatározták a járványos betegségek elleni védekezés alapelveit, egységesítették a karanténok múködtetését, és nemzetközi együttmúködést alakítottak ki, mely előfutára lett az 1946-ban alapított Egészségügyi Világszervezetnek (WHO).

A karanténok nem tévesztendők össze a menekülttáborokkal, ahova az adott országba okmányok nélkül bejutni szándékozókat különítik el, míg el nem dől, hogy azok menedékkérők (azaz üldöztetés elől menekülnek) vagy emigránsok (az utóbbi időkben csak migránsoknak nevezik őket), akik a jobb élet reményében hagyják el származási helyüket. A nem megfelelő higiéniával rendelkező táborokban vagy szükségtáborokban (amelyek egy-egy nagyobb néptömeg bezúdulására nincsenek felkészülve) természetesen felütheti járvány a fejét. Ismeretes a fertőzöttek vagy a fertőzöttnek feltételezett csoportok elkülönítése is: ez nem karantén, hanem úgynevezett egészségügyi záróövezet (nemzetközi névvel „cordon sanitaire”), hogy a fertőzött emberek ne hagyják el lakóterületüket, és így ne exportálják a fertőzést más városrészekbe. 


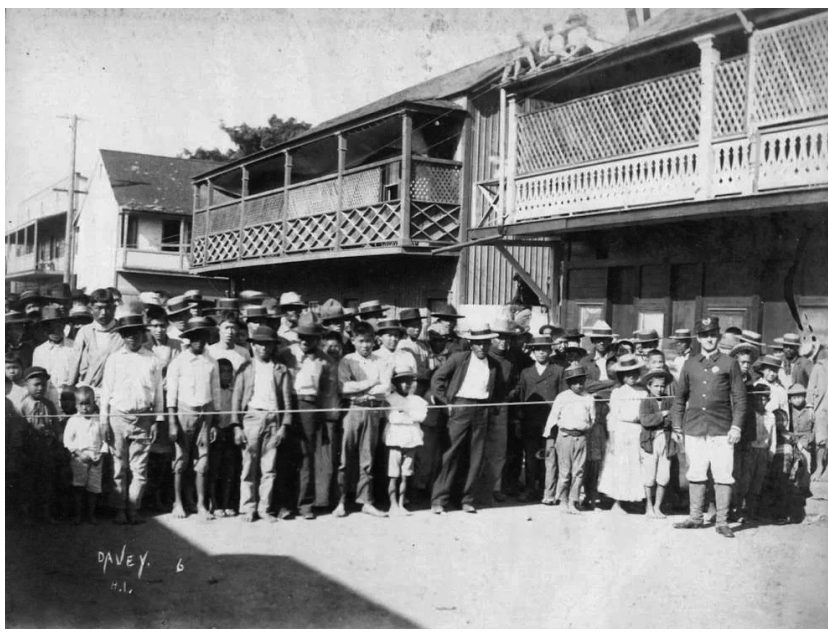

6. ábra

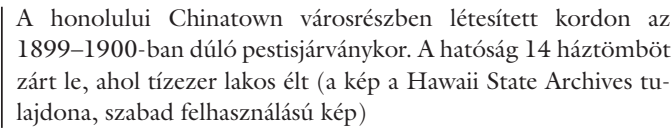

San Francisco egyik hoteljében 1900-ban egy kínai bevándorló holttestét találták a hatóságok, akiről kiderült, hogy bubópestisben szenvedett. Azonnal körülzártak szögesdróttal egy 12 háztömbnyi városrészt a kínai negyedben - miután a fehéreket kiengedték a területről. Bár pár nap múlva a kordont megszüntették, ezalatt sok kínai elvesztette a munkáját. A „bubóblöff” hatására majdnem kitoloncolták az összes kínai emigránst az államból. Hasonló eset történt Honoluluban (6. ábra).

A karanténtörvények alkalmazása mindig is politikai viták tárgyát képezte. Ezért a tbc-s betegek izolálóhelyét a 20. század első felétől kezdve már nem karanténnak, hanem eufemisztikusan szanatóriumnak nevezték: itt az izolálás mellett a betegek gyógyítása is helyet kapott. Úgy tünt, hogy a karanténok használata a 20. század második felében már a múlté. A nemzetközi utazások nagy száma, a kikötők és a repülőterek hihetetlen forgalma és az a tény, hogy a világ bármely tájáról származó járvány órák alatt megjelenhet sok ezer kilométerrel arrébb, lehetetlenné teszi a karanténok használatát. A karanténok feleslegessé váltak. De valóban feleslegesek?

Földön Kívüli Ártalmak Törvénye [15] volt a népszerü elnevezése annak a törvénynek, melyet az USA kormánya 1969-ben léptetett életbe. A törvény célja az ûrből származó kórokozók biológiai kontaminációjának megakadályozása volt. A törvény az Apolló-11 ürhajósainak karanténba helyezését törvényesítette. A karantén alkalmazása lehetővé tette, hogy megakadályozzák az esetleges ismeretlen holdi mikroorganizmusok földi elterjedését. A tengerbe való leereszkedés után a kimentő búvárok vitték magukkal az ûrhajósok számára az izolációs ruházatot, amellyel a kabinajtó kinyitásának pillanatától karanténba helyezték a három holdutazót (7. ábra).

A helikopter a fedélzetére vette Armstrongékat, közben a búvárok hipóval fertőtlenítették a kabint. Az ưrhajósokért érkező repülőgép-anyahajón mobil karanténba kerültek az asztronauták, majd az Apolló-1l

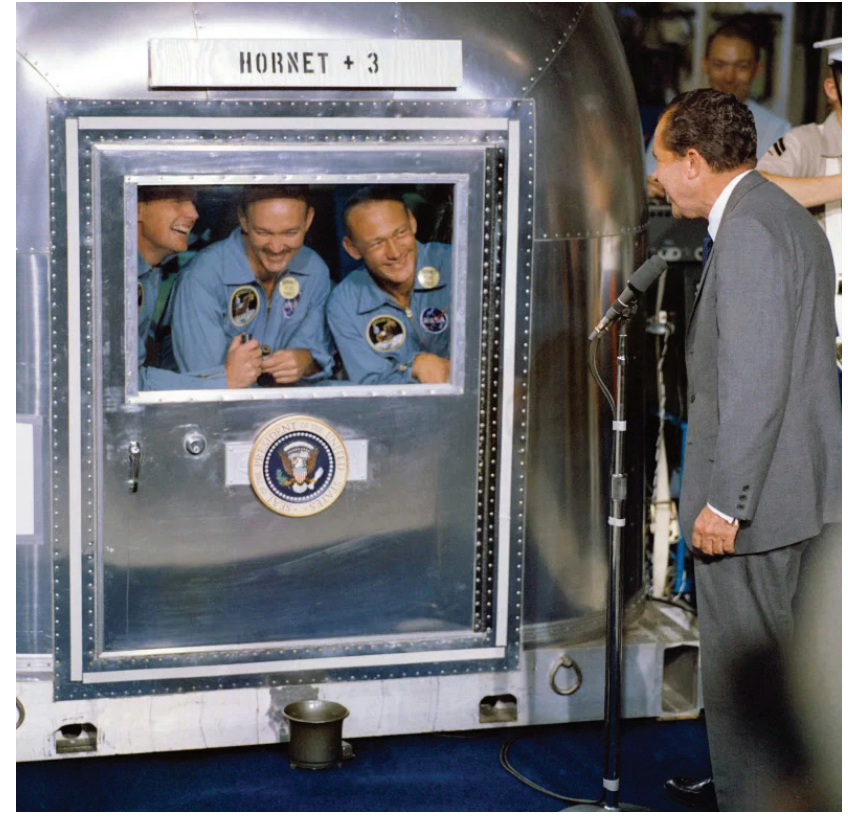

7. ábra

1969-ban Nixon amerikai elnök üdvözli a Holdról visszatérő ưrhajósokat a Hornet anyahajón, ahol az asztronautákat mobil karanténba helyezték (NASA/Wikimedia, szabad felhasználású kép)

utasai 23 napot töltöttek a NASA houstoni ûrközpontjának Lunar Receiving Laboratory elnevezésü izolált részében. A 21 napos karanténidőt az USA Tudományos Akadémiájának Ürkutatási Csoportja elegendőnek tartotta [16]. A karanténrendelkezést már nem alkalmazták az Apolló-13 ûrutazása után, és 1991-ben a törvényt is hatályon kívül helyezték, mivel a mikrobiológiai, állat- és növénykísérletek kimutatták, hogy a Hold felszíne steril.

A holdra szállási programot mégsem az ürből jövő, hanem földi fertőző betegség fenyegette: az Apolló-13 startja előtt a holdkomp tartalék pilótája kanyaróban megbetegedett. Mivel a kijelölt és a tartalék személyzet együtt gyakorlatozott, és ezáltal fennállt a kontamináció lehetősége, a személyzet egy részét (akik nem voltak immunisak a morbilli ellen) le kellett cserélni.

A SARS-világjárvány (pandémia) kitörése 2003-ban a karantén elveinek feléledését is jelentette. A „fehér pestis", azaz az antibiotikumrezisztens tbc, majd késóbb a megjelenő új pandémiák (AIDS, Creutzfeldt-Jakob-betegség, madárinfluenza, sertésinfluenza), valamint a régi betegségek (pestis) helyi fellángolása, a bioterrorizmus fenyegetései meghozták a karanténok reneszánszát [17].

Szomorú aktualitást ad ennek a történelmi áttekintésnek a 2019-ben kitört COVID-19 elnevezésű vírusjárvány. Sajnálatos módon a magyar társadalom is megismerhette a „karantén” fogalmát - ha nem is külön épített tömegszállásokon, hanem csak otthon vagy a kijelölt kórházak kórtermeiben. Az otthoni karanténnak több formája ismeretes: ha a betegeket vagy fertőzésgyanús személyeket egy speciális helyiségben vagy kórteremben izolálják, és csak védőruhában közelednek hozzájuk, ezt 
Magyarországon járványügyi zárlatnak nevezzük. A fertőzés elmúltával (amikor a kórokozót kimutató laborvizsgálat rendszerint negatív, tehát a kórokozó már nincs jelen a vérkeringésben, így az egyén nem fertőző) a gyógyult beteg vagy megfigyelt személy elhagyhatja a karantént. Ha a megfigyelés az egyén otthonában (külföldiek esetén a szállodai szobában) zajlik, akkor járványügyi megfigyelésről, magyarul izolálásról beszélünk. A megfigyelt személlyel ekkor sem szabad érintkezni. Így a modern karanténok már nemcsak izolálják és gyógyítják a betegeket, de hathatós prevencióul is szolgálnak a társadalom védelmére [18].

A karanténok létjogosultságáról széles körű viták folynak. Mivel a karanténintézkedések blokkolják az idegenforgalmat, a kereskedelmet, hatalmas gazdasági veszteséget okoznak ezeknek az iparágaknak, és hatásai továbbgyúrüznek a többi gazdasági ágazatra is. Másik igen vitatott hatásuk az állampolgári jogok olyan mértékű csorbítása, hogy az felelőtlen vagy diktatórikus politika kezében veszedelmes elnyomó fegyverré válhat. Vitatott az egyes járványok elleni preventív hatásuk is: például a SARS ellen hiába hirdetnek karantént, az csak akkor fertőz, ha a betegség már tüneteket ad [19]. A jelenlegi COVID-járványnál ez szintén így van, de megfigyeltek fertőzőképességet a tünetek megjelenése előtt is. A zoonosisoknál pedig a karantén egyedül nem nyújt védelmet a betegség terjedésével szemben: azt egyéb járványügyi intézkedéseknek is ki kell egészíteniük. Sajnálatos módon a karantén olyan betegségeknél sem hatásos (például influenza), amelyek már a tünetek megjelenése előtt is fertőznek.

Bár a gyógyszerek, antibiotikumok és antivirális szerek megjelenésével sok fertőző betegség gyógyíthatóvá vált, nem mindegyik. Sok fertőző betegség ellen ma éppúgy nincs specifikus gyógyszer, mint a középkorban a járványok idején. Ezért a karanténokkal együtt a modern közegészségügyi módszerek is átvették a járvány elleni régi védekezési módszereket: a határellenőrzést, a kontaktkutatást, az izolációt és a megfelelő távolságtartást.

\section{Irodalom}

[1] Mullett CF. A century of English quarantine (1709-1825). Bull Hist Med. 1949; 23: 527-545.

[2] Howard J. An account of the principal lazarettos of Europe: with various papers relative to the plague, together with further observations on some foreign prisons and hospitals; and additional remarks on the present state of those in Great Britain and Ireland. 2nd edn. Johnson J, Dilly C, Cadell T, London, 1791.

[3] Penn-Barwell JG, Sir Gilbert Blane FR. The man and his legacy. J R Nav Med Serv. 2016; 102: 61-66.

[4] Szókefalvi NZ, Spielmann J. Recent data on life and activity of Ferenc Nyulas. In: Paczolay Gy, Gazda I. (eds.) Five studies on
Ferenc Nyulas (1758-1808), chief doctor of Transylvania, the first author of analytical chemistry in Hungarian language. [Nyulas Ferenc életére és múködésére vonatkozó újabb adatok. In: Paczolay Gy, Gazda I. (szerk.) Öt tanulmány az első magyar nyelvú analitikai kémiai munka szerzőjérôl, Erdély főorvosáról, Nyulas Ferencről (1758-1808).] A Magyar Tudománytörténeti Intézet Tudományos Közleményei 2007; 63: 162. [Hungarian]

[5] Balázs P. Generale normativum in re sanitatis, 1770. [Szervezett egészségügyünk 1770-es alaprendelete.] Magyar Tudománytörténeti Intézet, Semmelweis Orvostörténeti Múzeum, Könyvtár és Levéltár, Piliscsaba-Budapest, 2004; Vol. II, pp. 246-373. [Hungarian]

[6] Reizner J. The history of Szeged. [Szeged története.] Szeged Szabad Királyi Város Közössége, 1899-1900; Vol. III, p. 171. [Hungarian]

[7] The plague doctor. In: Magyari-Kossa Gy. Hungarian medical memories. Volume 1. [A pestisorvos. In: Magyari-Kossa Gy. Magyar orvosi emlékek. 1. kötet.] Magyar Orvosi Könyvkiadó Társulata, Budapest, 1929; p. 121. [Hungarian]

[8] Evidences to the history of the plague from 1738-1743. In: Magyari-Kossa Gy. Hungarian medical memories. Volume 2. [Adatok a 1738-1743. évi pestis történetéhez. In: MagyariKossa Gy. Magyar orvosi emlékek. 2. kötet.] Magyar Orvosi Könyvkiadó Társulata, Budapest, 1929; p. 147. [Hungarian]

[9] Kiss L. The dispute about the infectivity of cholera in Orvosi Tár - its effect on the acceptance of Semmelweis' doctrine. [Diskurzus a kolera ragályosságáról az Orvosi Tárban - hatása a Semmelweis-tan elfogadására.] Orv Hetil. 2020; 161: 1534-1536. [Hungarian]

[10] Markel H. Quarantine! East European Jewish immigrants and the New York City epidemics of 1892. Johns Hopkins University Press, Baltimore, MD, 1997.

[11] Bryant JE, Holmes EC, Barrett AD, et al. Out of Africa: a molecular perspective on the introduction of yellow fever virus into the Americas. PLoS Pathog. 2007; 3: e75.

[12] McDonald J, Shlomowitz R. Mortality on convict voyages to Australia 1788-1868. Soc Sci Hist. 1989; 13: 285-313.

[13] New South Wales Government Office of Environment and Heritage: North Head Quarantine Station \& Reserve. Available from: https://www.environment.nsw.gov.au/heritageapp/ ViewHeritageItemDetails.aspx?ID=5045740 [accessed: October $1,2020]$.

[14] Sealey A. Globalizing the 1926 international sanitary convention. J Glob Hist. 2011; 6: 431-455.

[15] Extra-Terrestrial Exposure Law. Code of Federal Regulations, 1999. 14 CFR $\$ 1211$

[16] Johnston RS, Mason JA, McCollum GW, et al. The lunar quarantine program. Biomedical Results of Apollo, Sect V. Chapter 1. Lyndon B. Johnson Space Center, 1963.

[17] Gensini A, Yacoub A, Conti A, et al. The concept of quarantine in history: from plague to SARS. J Infect. 2003; 49: 257-261.

[18] US Department of Health and Human Services: pandemic influenza plan 2009, Attachment 12: principles of modern quarantine. Available from: [accessed: November 25, 2020].

[19] Schabas R. Severe acute respiratory syndrome: did quarantine help? Can J Infect Dis Med Microbiol. 2004; 15: 204.

(Felkai Péter dr., Budapest, Szentendrei út 301., 1039 e-mail: peter.felkai@soshungary.hu)

A cikk a Creative Commons Attribution 4.0 International License (https://creativecommons.org/licenses/by/4.0/) feltételei szerint publikált Open Access közlemény, melynek szellemében a cikk bármilyen médiumban szabadon felhasználható, megosztható és újraközölhető, feltéve, hogy az eredeti szerző és a közlés helye, illetve a CC License linkje és az esetlegesen végrehajtott módosítások feltüntetésre kerülnek. (SID_1) 